\title{
CZESŁAW MIŁOSZ I JAN NOWAK-JEZIORAŃSKI PROTOKÓŁ ROZBIEŻNOŚCI
}

\author{
Emil PASIERSKI (Wrocław)
}

Nie najwdzięczniejsze to i nie najprostsze zadanie opisać relacje Czesława Miłosza i Jana Nowaka-Jeziorańskiego. Bo choć z jednej strony obaj byli w historii Polski XX wieku postaciami wybitnymi - symbolicznymi wręcz dla swoich czasów — to z drugiej strony opowiadanie o ich wzajemnych stosunkach jest $\mathrm{w}$ istocie narracją o nieufności, dwustronnym niezrozumieniu, niechęci i konflikcie. Dodajmy, że narracją dość krótką, opartą na niewielkiej liczbie przekazów. A jakie były przyczyny obopólnych kontrowersji? Bez wątpienia złożone. Można brać pod uwagę silne temperamenty z wyostrzonym instynktem zachowania autonomii, a także różne tradycje, światopoglądy i nieprzystające modele patriotyzmu, które w polskich warunkach bardzo rzadko zazębiały się ze sobą bezkonfliktowo, do tego odmienna aksjologia — by wymienić kilka najoczywistszych czynników.

Monografie okołoliterackiej działalności Rozgłośni Polskiej Radia Wolna Europa pod wodzą Nowaka w kwestii współpracy z Miłoszem sumiennie odnotowują większe, a zazwyczaj jednak mniejsze przejawy obecności jego dzieł na falach radiostacji, lecz nie są mimo wszystko z oczywistych powodów w stanie wyjść poza ramy bolesnego być może dla wielu stwierdzenia o faktycznym braku takowej kooperacji ${ }^{1}$. Bo choć lista pisarzy współpracujących z RWE w ciągu lat była bardzo długa i otwarta na ludzi o zróżnicowanych poglądach, to próżno szukać na niej poety, który, można powiedzieć, był jednym z głównych i zarazem nielicznych „,wielkich nieobecnych”. Jerzy Giedroyc nie bez kozery pisał w liście do Miłosza: ,[...] FE posiada jakąś dziwną siłę atrakcyjną. Ze znanych mi pisarzy jesteś bodaj jedynym, który z FE nie współpracuje. Znajdując

${ }^{1}$ Zob. m.in.: K.W. Tatarowski, Literatura i pisarze w programie Rozgłośni Polskiej Radia Wolna Europa, Kraków 2005; V. Wejs-Milewska, Radio Wolna Europa na emigracyjnych szlakach pisarzy: Gustaw Herling-Grudziński, Tadeusz Nowakowski, Roman Palester, Czesław Straszewicz, Tymon Terlecki, Kraków 2008. 
na to dziesiątki wyjaśnień"2. Decydujące znaczenie, co potwierdzają kolejne źródła publikowane na przestrzeni ostatnich lat ${ }^{3}$ — łącznie z korespondencją Miłosza i Nowaka zatrzymaną niegdyś przez Redaktora Giedroycia i upublicznioną dopiero po śmierci obu bohaterów niniejszego szkicu ${ }^{4}$ - wydaje się mieć tu konflikt personalny. Prześledzenie jego historii dostarczy wielu odpowiedzi na nasuwające się w tym kontekście pytania.

Z perspektywy Miłosza sprawa kontaktów z RWE wyglądała nad wyraz klarownie. Biograf Kuriera z Warszawy odnotował nawet dość węzłowato kluczowe punkty jego oceny tej instytucji:

Czesław Miłosz nienawidził RWE. Dla niego rozgłośnia reprezentowała tylko ślepy antykomunizm i skupiała typowych londyńskich emigrantów. Takich, którzy na początku lat 50., po jego decyzji, by pozostać na Zachodzie, opluwali go za to, że „wysługiwał się warszawskiemu reżimowi" ".

Inny wnikliwy obserwator tych relacji, a momentami nawet ich moderator, o którym z wielu względów nie wypada tu zapomnieć — Jerzy Giedroyc — podawał natomiast:

Moje stosunki z Wolną Europą nigdy nie były najlepsze, ale on [Miłosz] uważał Wolną Europę za instytucję niesłychanie szkodliwą i na tym tle też dochodziło do spięć. M.in. gdy zrzucono do Kraju w ramach tzw. akcji balonikowej Zniewolony umyst, z którego zrobiono miniaturowe wydanie, o czym zresztą nikt $\mathrm{z}$ nas nie wiedział $\mathrm{i}$ co było pod tym względem posunięciem dość gangsterskim. Wybuchła kolosalna awantura. Miłosz chciał wytaczać proces, ale do tego nie było niestety podstaw ${ }^{6}$.

Sam Miłosz - poza korespondencją — nie poświęcił wiele miejsca w swej twórczości kontaktom z Wolną Europą i z Janem Nowakiem-Jeziorańskim, co nie wydaje się bez znaczenia. W nielicznych tego typu wzmiankach akcentował jednak przede wszystkim kwestię zależności rozgłośni od amerykańskich funduszy, z lubością przeciwstawianą niezależności „Kultury” i Jerzego Giedroycia, krytykując jednocześnie także propagowany na antenie model patriotyzmu, osadzony głęboko w dość konserwatywnym nurcie polskiego katolicyzmu i negatywnie oceniając monopolistyczne reguły współpracy

2 J. Giedroyc, Cz. Miłosz, Listy 1964-1972, oprac. M. Kornat, Warszawa 2011, s. 64 (list z 8 grudnia 1964).

${ }^{3}$ Zob. m.in.: J. Nowak-Jeziorański, J. Giedroyc, Listy 1952-1998, wyb., oprac. i wstęp D. Platt, Wrocław 2002; J. Giedroyc, Cz. Miłosz, Listy 1952-1963, oprac. i wstęp M. Kornat, Warszawa 2008; J. Giedroyc, Cz. Miłosz, Listy 1964-1972, oprac. M. Kornat, Warszawa 2011; J. Giedroyc, Cz. Miłosz, Listy 1973-2000, oprac. M. Kornat, Warszawa 2012; Cz. Miłosz, K. A. Jeleński, Korespondencja, red. B. Toruńczyk, oprac. R. Romaniuk, Warszawa 2011.

${ }^{4}$ Cz. Miłosz, Przyczynek do dziejów literatury na emigracji, Zeszyty Historyczne 2005 z. 152. W tekście tym, powstałym na przełomie 1964 i 1965 roku, komentował Miłosz list Nowaka, zapraszający go do współpracy z RWE, i swą odpowiedź odmowną. Obydwa listy zachowały się zarówno w archiwum Miłosza w Beinecke Rare Book and Manuscript Library w Yale (series V: Professional Papers, box 178, folder 2772), jak i w archiwum Jana NowakaJeziorańskiego zdeponowanym w Zakładzie Narodowym im. Ossolińskich we Wrocławiu (Korespondencja 1944-1975, sygn. 82-100/99, t. 32).

5 J. Kurski, Jan Nowak-Jeziorański. Emisariusz wolności, wstęp W. Bartoszewski, Warszawa 2005 , s. 119.

${ }^{6}$ J. Giedroyc, Autobiografia na cztery ręce, oprac. K. Pomian, Warszawa 1994, s. 162. 
z emigrantami ${ }^{7}$. Dość reprezentatywny dla całości jest opis świadomości Miłosza na początku lat 50., pochodzący z tomu Zaraz po wojnie:

[...] zdawałem sobie sprawę, z czego żyją piszący emigranci. Ich źródłem zarobku była zimna wojna, a takie instytucje jak Wolna Europa korzystały z przywilejów monopolisty. Zbyt krnąbrny, żeby się przystosować, co miałem do wyboru? Iść pracować w fabryce albo na stacji benzynowej? ${ }^{8}$

Niejako rozwinięciem podjętej w nim myśli na temat własnego losu, ale i stosunku do RWE, jest fragment Abecadta:
Jak to się udało i gdzie, w trudnej Francji, bez żadnej posady? Myśląc o tym, czuję strach, ale po fakcie. Była oczywiście „Kultura”, ale, sama uboga, mogła zdobyć się tylko na skromne honoraria. W dodatku pośród emigrantów byłem bodaj jedynym, któ- ry odmówił pisania do Wolnej Europy, bo nie podobało mi się jej bicie w patriotyczny bęben i kropienie święconą wodą ${ }^{9}$.

Jak widać, od strony Miłosza sytuacja — chociaż jasna — była też jednak wyraźnie zaogniona i w najmniejszym stopniu nie łagodziły jej oczywiste wyjątki od przekrojowych opinii cytowanych powyżej, jak choćby fakt, że w gronie osób zrekrutowanych przez Nowaka do pracy w Rozgłośni Polskiej RWE był np. Kazimierz Zamorski jeden z sygnatariuszy opublikowanego na łamach „Kultury” Oświadczenia, biorącego Miłosza $\mathrm{w}$ obronę i sprzeciwiającego się atakom na poetę $\mathrm{w}$ prasie emigracyjnej ${ }^{10}$. Znacznie donioślejszą rolę wydawały się odgrywać jednak reguły przeczące tym chlubnym wyjątkom, uosabiane w tym przypadku zwłaszcza przez Wiktora Trościankę, który w oczach poety, ale i nie tylko, uchodził za jednego z najbardziej nieprzejednanych jego wrogów wśród personelu RWE ${ }^{11}$.

Z perspektywy Nowaka sprawa się już nieco komplikowała. Po pierwsze pochodzące od niego przekazy na temat Miłosza - abstrahując jeszcze od ich nacechowania emocjonalnego - nie są już tak jednorodne, a bywa też, że po trosze się wykluczają, jak choćby w przypadku, gdy był pytany o wzór pisarza politycznego i dziennikarza; odpowiedzieć miał:

W okresie powojennym, zwłaszcza kiedy byłem w Wolnej Europie, wielkie wrażenie zrobił na mnie i stał się ogromną pomocą Miłosza Zniewolony umyst. Był niejako kluczem dla zrozumienia mentalności kolaborujących z systemem sowieckim intelektualistów ${ }^{12}$.

Chwaląc książkę Miłosza w jednym miejscu, w innym potrafił zdobyć się natomiast na iście brawurową wzmiankę na temat uchodźców z Polski, głoszącą ni mniej, ni więcej: „od czasów ucieczki Mikołajczyka, Korbońskiego i innych przywódców PSL-u w 1947 roku — aż do wiosny 1953 roku nie było ani jednego głośnego wypadku wybrania wolności przez wybitną osobistość polską ${ }^{13}$ ". Ponadto Nowak jako udzielny władca

${ }^{7}$ Zob. m.in. szkice: Tajemniczy pomnik i Zosia Hertz włączone do tomu Życie na wyspach (Kraków 1997). Spośród innych wyimków z Miłosza na ten temat warto zwrócić uwagę także na rozmowę poety z Jerzym Illgiem pt. Grozi nam plaskość i wulgarność, [w:] Cz. Miłosz, Rozmowy polskie 1979-1998, Kraków 2006.

${ }^{8}$ Cz. Miłosz, Zaraz po wojnie. Korespondencja z pisarzami 1945-1950, Kraków 2007, s. 592.

${ }^{9}$ Tenże, Abecadło, Kraków 2001, s. 243.

${ }^{10}$ Kultura $1951 \mathrm{nr} 12$ (50), s. 3.

${ }^{11}$ Poeta poświęcił Trościance m.in. jedno $\mathrm{z}$ haseł w swym Abecadle.

12 J. Nowak-Jeziorański, Fakty, wydarzenia, opinie, Warszawa 2001, s. 40.

${ }^{13}$ Tenże, Wojna w eterze, Kraków 2005, s. 115. 
całkiem rozległego imperium medialnego, jak byśmy dziś to nazwali, nie musiał swych opinii wyrażać bezpośrednio. Mógł dawać im wyraz również przez takie, a nie inne posunięcia kadrowe czy programowe.

Pierwszym i głównym powodem do nawiązania kontaktu Nowaka z Miłoszem był oczywiście rzeczony już Zniewolony umyst, opublikowany w lutym 1953 roku przez Instytut Literacki ${ }^{14}$. Wcześniej, np. gdy przyszły szef sekcji polskiej kompletował swój monachijski zespół, taka ewentualność nie była najwyraźniej w ogóle brana pod uwagę, co w kontekście bogatych przecież doświadczeń Miłosza, jako pracownika Polskiego Radia w Wilnie i w Warszawie (1935-1939), każe domyślać się powodów takiego zaniechania i przyczyn szukać właśnie po stronie negatywnego stosunku do poety, którego decyzja o pozostaniu na Zachodzie w 1951 roku, przypomnijmy, została przyjęta przez koła emigracyjne z mieszanymi uczuciami, zwłaszcza w Londynie. Oliwy do ognia dolało wkrótce jeszcze majowe wystąpienie poety z głośnym artykułem $\mathrm{Nie}^{15}$, w którym wyraźnie dawał on do zrozumienia, że nie ma zamiaru posypywać głowy popiołem.

Wrażenie, jakie wywarł jednak Zniewolony umyst, było na tyle silne, że odsunęło na dalszy plan ewentualne obiekcje. Już w czerwcu 1953 roku Jerzy Giedroyc relacjonował w liście Józefowi Wittlinowi:

Niewątpliwie książka Miłosza przełamała w dużym stopniu nastroje. Ostatnio F[ree] E[urope] z Monachium zwróciło się z prośbą o zgodę na recytację ustępów Zniewolonego umystu. Biorąc pod uwagę wrogi wręcz stosunek sekcji polskiej w Monachium do niego, to jest duży postęp ${ }^{16}$.

Istotnie, w amerykańskim archiwum poety zachowało się datowane na 14 grudnia 1953 roku zezwolenie na wykorzystanie w audycjach emitowanych do krajów Bloku Wschodniego fragmentów Zniewolonego umystu ${ }^{17}$. Co ciekawe - Miłosz, podpisując ów dokument, wprowadził w nim niebagatelną poprawkę, wykreślając z grona dopuszczonych państw Polskę, gdzie cieszący się tam zakazaną sławą zbiór esejów nie mógł być odtąd legalnie rozpowszechniany przez radiostację. Czy autor chciał w ten sposób zadbać o prawa polskiego wydawcy książki, tj. Jerzego Giedroycia? Czy w decyzji tej był może już zalążek późniejszych bolączek Miłosza, który wyjątkowo nie cenił sobie splendoru spływającego nań tylko dzięki Zniewolonemu umystowi i już wkrótce zaczął zwalczać wszelkimi środkami przyszywaną mu łatkę pisarza politycznego? Było bardzo prawdopodobne, że takie uznanie, pochodzące na dodatek ze strony RWE, tym bardziej doskwierało poecie i nie było powodem do satysfakcji. Wprawdzie dla rozgłośni książka była bardzo przydatnym narzędziem walki propagandowej, „kluczem jak mówił Nowak - do zrozumienia mentalności kolaborujących z systemem sowieckim intelektualistów”, jednak Miłosz miał prawo obawiać się, że będzie ona wykorzystywana jako wytrych, pozbawiając samego autora podmiotowości i redukując jego rolę do rangi analityka czy obdarzonego sprawnym piórem politologa. Niewiele wskazywało, że mogłoby być inaczej...

Wkrótce w listopadzie 1954 roku Miłosz dostał zaproszenie do wzięcia udziału w noworocznej ankiecie radia, prezentującej głosy „,najwybitniejszych przedstawicieli

\footnotetext{
${ }^{14}$ Cz. Miłosz, Zniewolony umyst, Paryż 1953, Biblioteka „Kultury” t. 3.

${ }^{15}$ Kultura 1951 nr 5 (43), s. 3-13.

${ }^{16}$ M. Ptasińska-Wójcik, Z dziejów Biblioteki Kultury 1946-1966, Warszawa 2006, s. 121 (list z 29 czerwca 1953).

17 Beinecke Rare Book and Manuscript Library, Czeslaw Milosz Papers, series I: Correspondence, box 52, folder 741 .
} 
kultury polskiej na emigracji” na temat ich planów na nadchodzący rok $^{18}$. Reakcja poety, utrwalona w liście do Jerzego Giedroycia, okazała się jednak nad wyraz nieufna i nerwowa, co najlepiej obrazuje początkowy stan wzajemnych relacji z Nowakiem:

[...] zwróciło się do mnie Radio Free Europe, sekcja polska, tzn. dostałem list podpisany Nowak i Palester - chcą, żebym opowiedział o swoich planach literackich etc. w ramie ankiety wśród pisarzy. Żebym to nagrał u Michałowskiego, który już mnie łapał w Paryżu telefonicznie. Otóż nie wiem, co z tym zrobić. Wie Pan, że to radio nie jest dla mnie szczególnie pachnące i że dobrej opinii w Polsce nie ma. Wolę zapytać, co Pan o tym sądzi, niż wlapać się [!] niepotrzebnie. [To pilne, niech Pan odpowie]. Oczywiście, że głos mój nagrany to znaczy „Miłosz przemawiał przez Free Europe”. Jeżeli zależy mnie, a pewnie i Panu jako „Kulturze”, na pewnej autonomiczności stanowiska, które by nas odcinało od pewnych robótek - a wie Pan, że to jest wszystko bardzo płynne i na zacieraniu granic szczególnie pewnym kołom zarówno za granicą, jak w Polsce zależy — to mnie się zdaje, że trzeba się nad tym zastanowić. [...] Wydaje mi się, że powinienem odmówić, albo, jeżeli chcę uniknąć zadrażnień, mogę się zgodzić na to, żeby Michałowski zrobił interview ze mną i podał jako swój artykuł, a nie mój osobisty speech. To zaproszenie jest zresztą dość charakterystyczne, ale podobne do zapraszań do Związku Pisarzy w Londynie ${ }^{19}$.

Nie wiemy, co Jerzy Giedroyc poradził poecie i czy był skuteczny. Faktem jest natomiast, że Miłosz nie odrzucił propozycji nawiązania bliższego kontaktu, przemowę nagrał i można jej do dziś nawet posłuchać ${ }^{20}$. Mimo że wzbudziło tyle obaw poety, nie było to jeszcze jednak zaproszenie do stałej współpracy. Na to trzeba było poczekać blisko rok i być może „zasłużyć”... Na przełomie lat 1954/1955 i w samym 1955 roku były co najmniej dwie okazje, dzięki którym Miłosz - zupełnie nieświadomie wzbudził zaufanie Nowaka - w obu przypadkach przyczynił się do tego Jerzy Giedroyc. Pierwszą z nich była planowana przez Redaktora w porozumieniu z Nowakiem wyprawa poety do obozu uchodźców w miejscowości Valka w celu napisania reportażu o panujących tam dramatycznych warunkach. Jeszcze przed publikacją w „Kulturze”21 tekst został wysłany do Monachium i zyskał spory entuzjazm Nowaka, który ocenił go jako „doskonale napisany” i chwalił jego wyważony charakter ${ }^{22}$.

Drugim przykładem może być kontekst tzw. „Listu 48” z sierpnia 1955 roku, w którym krajowi literaci na falach Radiostacji „Kraj” apelowali do emigrantów, by ci wracali. W liście do Redaktora Nowak wprost napisał wówczas, że Miłosz byłby najlepiej powołanym do odpowiedzi na takie apele ${ }^{23}$. Delikatne i ryzykowne przedsięwzięcie, w rozegranie którego zaangażowała się zarówno paryska „Kultura” jak i RWE, przyniosło jednak tylko połowiczny sukces. Wysuwany przez nich postulat zaproszenia krajowych sygnatariuszy do Maisons-Laffitte miał nie dojść do skutku właśnie z powodu Miłosza, którego obecność i przewodnictwo podczas rozmów były nie do przełknięcia dla strony krajowej ${ }^{24}$. Niemniej podczas akcji udało się w dużej mierze wykazać brak dobrej woli krajowych inicjatorów całego przedsięwzięcia i zdemaskować ich nieczyste zamiary.

\footnotetext{
18 Tamże.

19 J. Giedroyc, Cz. Miłosz, Listy 1952-1963, s. 200.

${ }^{20} \mathrm{http}: / /$ www.polskieradio.pl/68/2461/Audio/290142 [dostęp: 2 XII 2014].

${ }^{21}$ Cz. Miłosz, Valka, czyli poza czasem, Kultura 1955 nr 4 (90), s. 5-17; przedruk w: Kontynenty, Paryż 1958, Biblioteka „Kultury”, t. 29.

22 J. Nowak-Jeziorański, J. Giedroyc, Listy 1952-1998, s. 65.

${ }^{23}$ Tamże, s. 69.

${ }^{24}$ Tamże, s. 110.
} 
Widoczny wzrost zainteresowania Miłoszem poskutkował w końcu wysłaniem do niego przez Nowaka krótkiego zaproszenia do poprowadzenia na antenie cotygodniowej 10-minutowej audycji z cyklu List do komunisty, z gażą 125 dolarów miesięcznie ${ }^{25}$. List ów z 10 września 1955 roku, dość formalnie zwracający się z prośbą o nawiązanie współpracy, ponownie został przez Miłosza przyjęty chłodno. Po blisko dziesięciu latach poeta tak pisał o tym w komentarzu:

Wypada zauważyć, że list wieloletniego kierownika Rozgłośni Polskiej, Jana Nowaka, do polskiego poety jest pewnego rodzaju curiosum i wskazuje albo na słabą orientację co do tego kto był kto, albo, wyrażając się delikatnie, na brak taktu. Trzeba też wyjaśnić, że 125 dolarów i wtedy było sumą skromną, niemniej dla poety zamieszkałego we Francji i borykającego się z niedostatkiem, stanowiłaby ona poważną część miesięcznego budżetu. $\mathrm{O}$ wiele trudniej przyszłoby mu odpowiedzieć na ofertę odmownie, gdyby dotyczyła ona odczytów o literaturze, czyli treść listu decyzję odmowną ułatwiła ${ }^{26}$.

Z powyższego wynika, że mimo wszystko Miłosz nie zamierzał odrzucać oferty Nowaka a priori. Jasno pisał, że gdyby zlecenie opiewało na innego typu audycję, mógłby mieć co najmniej dylemat. Zapotrzebowanie RWE było jednak dokładnie sprecyzowane i skierowane ponownie nie tyle do Miłosza-poety, co do autora Zniewolonego umy$s h$, i to zapewne w znaczniej mierze go odstręczyło. W odpowiedzi utrzymanej w jak najbardziej uprzejmym tonie, odesłanej Nowakowi blisko dwa tygodnie później, tak motywowal poeta swą decyzję:

Mówiłem już Herlingowi, że łaskawej Pańskiej propozycji dostarczenia radiu Free Europe pogadanek List do komunisty nie mogę przyjąć. Powody są następujące:

Nigdy nie uprawiałem publicystyki politycznej w sensie popularnym i prawdopodobnie nie umiałbym tego robić.

Po drugie, linia ogólna radia Free Europe jest dla mnie niejasna, co wynika zapewne $\mathrm{z}$ tendencji całej instytucji, której audycje polskie są tylko odcinkiem. Zasadniczy cel: krytyki obecnego systemu w Polsce nie wyczerpuje sprawy, bo krytyka taka może być przeprowadzana $\mathrm{z}$ różnych stanowisk, nieraz diametralnie ze sobą sprzecznych. Obawiam się, że reprezentuję stanowisko, które, chociaż dość rozpowszechnione w Polsce, nie byłoby zgodne z linią Free Europe.

Wreszcie, mówienie o kwestiach politycznych do kraju byłoby dla mnie zbyt dużą odpowiedzialnością. Faktem jest, że nie mógłbym w tej dziedzinie ofiarować słuchaczom żadnego rozsądnego planu działania. Nie twierdzę, że jest to zasadniczo niemożliwe. Ograniczam się do uznania szeregu warunków, które to umożliwiają ${ }^{27}$.

Odmowa Miłosza nie pozostawiała Nowakowi wątpliwości, ale wydaje się też, że nie paliła mostów dla ewentualnej współpracy za jakiś czas i w innej formule. Można by zaryzykować tezę, że obie strony odłożyły taką możliwość na bliżej nieokreśloną przyszłość, gdyby nie to, że już wkrótce doszło do wydarzeń, które znacznie spotęgowały niechęć poety do RWE i szefa sekcji polskiej osobiście. W końcówce roku 1955 zaczęły bowiem pojawiać się w prasie krajowej sygnały o tajemniczym zrzucaniu zminiaturyzowanego wydania Zniewolonego umystu $\mathrm{z}$ baloników na terytorium Polski ${ }^{28}$. Po-

${ }^{25}$ Zob.: Cz. Miłosz, Przyczynek do dziejów literatury na emigracji, s. 131-132.

${ }^{26}$ Tamże, s. 131.

${ }^{27}$ Tamże, s. $132-133$.

${ }^{28}$ Jednym z pierwszych ,informatorów” był Jerzy Putrament, który w paszkwilu poświęconym Miłoszowi pisał: „W dosyć szybkim tempie pisze [Miłosz] książkę o 'zniewolonym umyśle'. Znajduje natychmiast wydawców, tłumaczy, reklamiarzy. Dzieło jego w specjalnej, kieszonkowej edycji ładuje się na dywersyjne baloniki. Chłopi na Dolnym Śląsku znajdują je od 
nieważ była to jedna z metod pracy Wolnej Europy, podejrzenia szybko padły w tamtą stronę. W styczniu 1956 roku Giedroyc pisał nawet do Nowaka:

Miłosz zamierza dać w najbliższym numerze „Kultury” suche sprostowanie à propos artykułu Putramenta o nim. Ponieważ prostuje między innymi zarzutami o zrzucaniu Zniewolonego umystu na balonikach do Polski, wolę Pana o tym z góry uprzedziće ${ }^{29}$.

W lutowym numerze „Kultury” Miłosz odniósł się do licznych zarzutów, formułowanych pod jego adresem, w tym do ekspediowania książki balonami do Polski. Pisał m.in., że nic o tym nie wie i że „mogłaby to zrobić tylko Free Europe, ale wtedy zwróciłaby się do polskiego wydawcy, to jest 'Kultury' o zgodę na specjalne wydanie, co nigdy nie nastąpiło" ${ }^{\prime 3}$. Sprawa nie doczekała się ostatecznego wyjaśniła. Poeta chciał wytaczać nawet proces, ale brak było wystarczających dowodów, aby pokusić się o pewną wygraną. Sam Nowak w latach późniejszych pytany o to nieraz przez Giedroycia, zawsze odrzucał podejrzenia, sugerując, że ktoś inny włączył się do ówczesnej propagandowej rozgrywki - nawet nie Amerykanie ${ }^{31}$.

W takiej oto chłodnej, niewolnej od podejrzeń atmosferze docieramy do roku 1964, kiedy miejsce miał kulminacyjny moment $\mathrm{w}$ dziejach znajomości Miłosza z Nowakiem-Jeziorańskim. Bezpośrednim powodem do zabrania głosu przez poetę $\mathrm{w}$ sprawie Wolnej Europy stał się tym razem tzw. „List 34”, do którego nagłośnienia w świecie radiostacja walnie się przyczyniła. W swym komentarzu do tej sprawy, opublikowanym jako głos w ankiecie londyńskich „Kontynentów”, po raz kolejny wrócił poeta do swej krytycznej oceny RWE, rozwijając ją na konkretnym przykładzie:

$\mathrm{Z}$ tym radiem nigdy nie współpracowałem z powodów pryncypialnych, ani mnie ono ziębi, ani grzeje i wcale nie myślę, że w całej sprawie protestu [34. — E.P.] ścierały się dwa tylko obozy, choć zarówno rządowi w Warszawie, jak Wolnej Europie zależało na stworzeniu takiego wrażenia. Występując w obronie wolności słowa i żądając uczciwej prasy, sygnatariusze protestu działali wbrew interesom zarówno cenzorów, jak Radia Wolna Europa, którego wpływ jest proporcjonalny do ograniczeń, jakim w Polsce podlega informacja [...] Opinia moich kolegów w kraju o jej audycjach nie jest pochlebna: audycje te uchodzą za głos polskiego establishment, tylko że przedwojennego, i zwracają się przede wszystkim do tej klienteli, która wrażliwa jest na słownictwo uważane niegdyś za apanaż tzw. „ideologii narodowej”, ${ }^{32}$.

Pisząc w dalszej części tekstu o pogardzie, z jaką autorzy audycji polskich RWE w obliczu konieczności w rodzaju „Listu 34” sięgać musieli po intelektualistów o poglądach innych niż preferowane, wspomniał Miłosz także o „ukochanych kmiotkach”, którzy przy okazji poważniejszych spraw schodzili na dalszy plan. Błahe z pozoru sformułowanie wróciło jednak jak bumerang w niepodpisanym artykule polemicznym, opublikowanym w organie radiostacji — piśmie „Na Antenie” ${ }^{\text {”3 }}$. Tekst oburzył Miło-

czasu do czasu w zaroślach zdziczałych malin. Obawiam się, że eksplozje myślowe, które w ich umysłach wywołuje, są nieproporcjonalnie nikłe w stosunku do kosztów takiej metody kolportażu księgarskiego. Ale mniejsza z tym. Lepiej, aby dolary [...] szły na taką dywersję, niż na szpiegostwo i trotyl”; J. Putrament, Coś z Miłosza [przedruk w:] Dwa lyki Ameryki, Warszawa 1956, s. 151.

${ }^{29}$ J. Nowak-Jeziorański, J. Giedroyc, Listy 1952-1998, s. 96.

${ }^{30}$ Cz. Miłosz, List do Redakcji, Kultura 1956 nr 2 (100), s. 155.

${ }^{31}$ J. Nowak-Jeziorański, J. Giedroyc, Listy 1952-1998, s. 108 i 111.

${ }^{32}$ Cz. Miłosz, Ankieta w sprawie akcji 34-ch, Kontynenty 1964 nr 67-68, s. 5.

${ }^{33}$ Nieukochani kmiotkowie, Na Antenie 1964 nr 10, s. 7; przedruk: Cz. Miłosz, Przyczynek do dziejów literatury na emigracji (s. 128-130). 
sza, grzebiąc na długie lata możliwość ewentualnej bliższej współpracy poety z RWE. Nie tylko sama forma tekstu wydała mu się niestosowna, ale i ewidentna nieprawda, na którą od pierwszych momentów zwrócił uwagę. Warto przytoczyć kluczowy fragment:

Co do uwag p. Czesława Miłosza z Uniwersytetu Berkeley w Kalifornii, to i tutaj ograniczymy się do jego deklaracji o stosunkach między Radiem Wolna Europa a p. Miłoszem. Tak jest - tych stosunków nie było i nie ma. Do współpracowników, którzy użyczali swojego pióra Rozgłośni Polskiej Radia Wolna Europa, należy wiele najlepszych piór na emigracji: poeci, powieściopisarze, krytycy, filozofowie, eseiści. D o współpracy tej nie zapraszaliśmy p. Czesława Miłosza [wyróżnienie - E.P.]. Dlaczego — to już całkiem inna historia, jakby powiedział Kipling $^{34}$.

To wszystko, co nastąpiło potem, w coraz większym stopniu rujnowało wizerunek Nowaka w oczach Miłosza. Po stronie poety opowiedzieli się w tym sporze zdecydowanie m.in. Jerzy Giedroyc, Zygmunt Hertz i Konstanty Jeleński. Ten ostatni, współpracując przecież z Nowakiem, przedłożył mu projekt listu, prostującego treści zamieszczone w „Na Antenie” i zagroził jego publikacją w innych pismach, gdyby Nowak sam nie podjął się druku. Tekst nie został przyjęty, a spotkanie odbyte w tej sprawie zrelacjonował Jeleński Miłoszowi następująco:

[Nowak] przyjechał specjalnie do Paryża prosić mnie o złagodzenie stwierdzeń zawartych w moim liście skierowanym do „Na antenie” [...]. Dziś dopiero wysyłam mu odpowiedź, uściślając oczywiście, że jeśli nie opublikuje tego listu, zaprzestanę współpracy z Free Europe i że opublikuję ten list in extenso w „Kulturze” oraz „Kontynentach”. [...] napisałem mu także, iż przypominam sobie, że przed około dziesięciu laty mówiłeś mi o skierowanej przez nich do Ciebie propozycji współpracy. Zaprzeczył kategorycznie, lecz równocześnie przyznał, że zwracał się do Ciebie dwukrotnie: raz w związku ze Zniewolonym umystem, za drugim razem - z propozycją wywiadu o Twojej twórczości. Odnoszę wrażenie, że czuje się bardzo niezręcznie z powodu wielkiego nietaktu, jaki popełnił, toteż przyniósł obszerną dokumentację, chcąc mi udowodnić, że jego radio zawsze wyrażało się o Tobie $\mathrm{z}$ najwyższym uznaniem $\mathrm{i}$ że on sam nigdy nie zwracał się do niechętnych Tobie ludzi z Londynu z prośbą o artykuły krytyczne o Twoich $\mathrm{książkach}^{35}$.

Za radą m.in. Jeleńskiego Miłosz zlecił wówczas przygotowanie przez kancelarię prawną pisma, wzywającego do sprostowania ${ }^{36}$. Zostało ono wkrótce wysłane, nie przynosząc jednak rezultatu. W odpowiedzi Jeleńskiemu zawarł Miłosz najwnikliwszy chyba portret Nowaka, jaki wyszedł spod jego pióra:

[...] zachowanie się Nowaka w tej całej sprawie jest dla mnie zupełną zagadką. Rozumiem, że mógł puścić przez nieuwagę tę notatkę - moje twierdzenie w „Kontynentach”, że to radio jest pełne nienawistników eks-endeckich, dla których każdy intelektualista jest prawie Berią nie było wyssane z palca — ale jak interpretować jego kategoryczne zaprzeczenia? Uważałem go zawsze za człowieka, z którym wspólnego języka nigdy i w żadnych okolicznościach nie mógłbym znaleźć, ale jednak przestrzegającego pewnych moralnych kodeksów. To rzuca niestety światło na szlachetną narodową polską etykę operującą w małej skali i tylko dlatego niezdolną do poważniejszych gardło-

${ }^{34}$ Cz. Miłosz, Przyczynek do dziejów literatury na emigracji, s. 129.

${ }^{35}$ Cz. Miłosz, K. A. Jeleński, Korespondencja, s. 52. Tekst Jeleńskiego ukazał się w Listach do Redakcji, Kultura 1964 nr 12 (206), s. 161-162.

36 Beinecke Rare Book and Manuscript Library, Czeslaw Milosz Papers, series V: Professional Papers, box 178, folder 2772. 
wych rozróbek. Ale właściwie to przyznaję, że nie rozumiem. O próbie ściągnięcia mnie na współpracownika za pośrednictwem Herlinga-Grudzińskiego nie mógł przecie zapomnieć. Czy liczył na to, że listu nie przechowam i że nie będzie żadnych śladów? ${ }^{37}$

Słowa te, choć podsumowują poniekąd okres kontaktów Miłosza z Nowakiem, piastującym jeszcze funkcję szefa Rozgłośni Polskiej RWE, to nie wyczerpują całości kontaktów poety z ludźmi radiostacji. Warto w tym miejscu wspomnieć o bardzo sympatycznym skądinąd liście Zygmunta Michałowskiego — przyszłego zastępcy, a potem następcy Nowaka - z grudnia 1960 roku do Miłosza świeżo urządzającego się po przeprowadzce do Stanów Zjednoczonych, w którym tytułował poetę „Kochany Panie i Drogi Mistrzu", informując go o uzgodnionym z szefem pozwoleniu na wysyłanie mu materiałów prasowych, a także o kolejnych dwóch zaproszeniach od Romana Palestra do wzięcia udziału $w$ ankietach dotyczących własnej twórczości ${ }^{38}$. Pierwsze $\mathrm{z}$ nich napisane zostało 9 lutego 1961 roku i wiązało się z nadchodzącą Wielkanocą, drugie natomiast jest o tyle ciekawe, że wyszło 29 października 1964 roku, a więc zaledwie cztery dni po dacie widniejącej na numerze „Na Antenie”, w którym ukazali się Nieukochani kmiotkowie...

Po tym, gdy z końcem 1975 roku Nowak odszedł z Rozgłośni Polskiej RWE, w jego kontaktach $z$ Miłoszem nie nastąpił przełom. Pewna zmiana stała się widoczna za to w relacjach poety z samą instytucją. Na ile to stopniowe zbliżenie było możliwe dzięki nieobecności Nowaka, a na ile zdecydowały o tym inne czynniki — np. werdykt Akademii Noblowskiej w 1980 roku czy 13 grudnia rok później — trudno dziś rozstrzygać. Faktem jest, że od lat 80. poeta pojawiał się częściej na falach RWE, m.in. w wywiadach, z których pierwszym był ten udzielony 7 listopada 1980 roku w Berkeley Annie Frajlich. Na samym jego początku Miłosz pragnął wyraźnie zaznaczyć swój stosunek do stacji:

Od trzydziestu lat jestem współpracownikiem Instytutu Literackiego w Paryżu, kierowanego przez Jerzego Giedroycia i współpracownikiem miesięcznika „Kultura”, wydawanego przez ten Instytut. Tam ukazały się prawie wszystkie moje książki i to jest coś, co oczywiście pozwala mi mówić z pewną kompetencją o działalności całej tego Instytutu, tego wydawnictwa. Nigdy natomiast nie pisałem, w ciągu tych trzydziestu lat, do Wolnej Europy. Jestem obywatelem amerykańskim, płacę podatki, jest to instytucja utrzymywana z moich podatków, bardzo pożyteczna jako źródło informacji. Gdyby to ode mnie zależało, na pewno bym zwiększył jeszcze na to kredyty, ale uważałem, że istnieje pewna hierarchia, którą trzeba utrzymywać. To jest, nigdy nie miałem wielkiej ochoty być dziennikarzem. Zresztą widziałem wielu ludzi zniszczonych przez dziennikarstwo. Natomiast współpraca z Instytutem Literackim i z „Kulturą” miała dla mnie zupełnie inny charakter ${ }^{39}$.

Co natomiast działo się dalej na linii Nowak-Miłosz? Wszystko wskazuje na to, że sytuacja w najmniejszym stopniu nie ulegała poprawie, a upływający czas nie łagodził przyczyn i skutków konfliktu, a wręcz przeciwnie - świetnie je konserwował. Z roku 1980 pochodzi najostrzejszy chyba obraz Nowaka, skreślony piórem poety. W liście do

\footnotetext{
${ }^{37}$ Tamże, fragment niepublikowanego listu Miłosza do Jeleńskiego z 12 listopada 1964.

${ }^{38}$ Tamże, series I: Correspondence, box 52, folder 741.

${ }^{39}$ Samotności nikt nie wybiera. Z Czesławem Miłoszem rozmawia Anna Frajlich, przedruk w: Cz. Miłosz, Rozmowy polskie 1999-2004, Kraków 2010, s. 270.
} 
Giedroycia, dotyczącym organizowania Nagrody Fundacji POLCUL, umieścił Miłosz nazwisko byłego dyrektora Rozgłośni Polskiej RWE wśród postaci, które w jego biografii zapisały się jak najgorzej:

\begin{abstract}
Jak wiesz, Boniecki z Australii montuje tę nagrodę i jesteś w jury, tak jak Gustaw i Kołakowski. Odpowiedziałem Bonieckiemu wątpliwościami co do jury rozsianego na kilku kontynentach, teraz przysłał mi plan, tj. kopię tego, co posłał Gustawowi. Istnieje jednak prawdziwy powód, dla którego w jury nie mogę wziąć udziału: udział w nim Jana Nowaka, którego uważam za kłamcę i skurwysyna. Tak samo nie zasiadłbym w jury z Ryszardem Wragą. Nie jestem zwolennikiem zasady: „pies mydło zjadł” i basta, czy też „buźka, kochajmy się”. Jeżeli nie mam zamiaru ściskać się z Putramentem, to nie ma powodu, żebym przyczyniał się do robienia z Nowaka czcigodnego starca. Swojego czasu nie chciałeś opublikować w „Dokumentach” materiałów, które Ci przysłałem, może zresztą słusznie, bo są to sprawy osobiste ${ }^{40}$. Tym niemniej zrobię z nich użytek, bo wyjaśniają stosunek Free Europe do mnie, głupotę jej dyrektora, który jakiegoś tam gówniarza rymopisa zapraszał do wygłaszania pogadanek pt. „List do komunisty”, a następnie nie miał tyle przyzwoitości, żeby do tego i do mojej odmowy się przyznać, wręcz przeciwnie, pozwolił swoim współpracownikom pisać, że Free Europe nigdy, mnie jednego spośród polskich pisarzy, do współpracy nie zapraszała. Ukazywanie się nazwiska Nowaka w „Kulturze” jest dla mnie wielką przykrością. Po żmudzku myślę: cierpliwości, zobaczymy, czyje będzie na wierzchu ${ }^{4}$.
\end{abstract}

Nowak, który wkrótce po odejściu z radia aktywnie włączył się w działalność Kongresu Polonii Amerykańskiej, przez wiele kolejnych lat nie miał istotniejszych powodów, by wypowiadać się na temat poety. Doceniał wprawdzie znaczenie Nagrody Nobla, zwracając jednakowoż uwagę na niebagatelny wkład Jerzego Giedroycia ${ }^{42}$, lecz w związku z tym, że Miłosz nie angażował się w życie polskiej diaspory, ich drogi nie krzyżowały się bezpośrednio. Nie jest tajemnicą, że nie bez powodu unikał poeta związków z polonią amerykańską. Jego krytyczny stosunek do tej społeczności stał się jednak pretekstem do zapytania Nowaka o to w jednym z wywiadów. Choć w udzielonej odpowiedzi dopatrzeć się można nawet dość sporej dawki woli zrozumienia i zracjonalizowania zachowań poety, to trudno oprzeć się wrażeniu, że milczeniem została pominięta kwestia tego, iż Nowak był niegdyś jednym z głównych graczy wśród polskiej emigracji i mógł mieć istotny wpływ na zupełnie inny obrót „sprawy Miłosza”:

Zastanawiam się, skąd się bierze ta niechęć Miłosza, który rzeczywiście trzymał się zawsze bardzo z dala od wszelkich instytucji i organizacji polskich, utrzymując kontakt i współpracę jedynie z paryską „Kulturą”. Wydaje mi się, że jest tutaj pewien kompleks, który wynika z tego, że bezpośrednio po Jałcie, bezpośrednio po wojnie, Miłosz znalazł się w obozie inteligencji czy intelektualistów popierających ten rząd - tzw. rząd ludowy - i podjął się jego reprezentacji na Zachodzie jako attaché kulturalny w ambasadzie w Paryżu. W tych latach, w tym czasie, kiedy emigracja żyła bezpośrednio pod wrażeniem zdrady jałtańskiej, to przejście na stronę wroga — bo w tym obozie komunistycznym widziano wroga - było traktowane nieomal jak zdrada. I Miłosz stał się przedmiotem ostracyzmu i nawet bardzo ostrych potępieńczych sądów wyrażanych głównie przez „Wiadomości” Grydzewskiego. Uratowała go właściwie jako pisarza „Kultura” - Jerzy Giedroyc, w którym pisarz i poeta znalazł swe oparcie. Trzeba pamiętać o ówczesnych nastrojach, które szły tak daleko, że doprowadziły nawet do pew-

\title{
${ }^{40}$ Zob. przypis 4.
}

${ }^{41}$ J. Giedroyc, Cz. Miłosz, Listy 1973-2000, s. 282 (list z 19 września)..

${ }^{42}$ Zob.: J. Nowak-Jeziorański, W poszukiwaniu nadziei, Warszawa 1993, s. 185-186; tegoż, Fakty, wydarzenia, opinie, s. 259. 
nego rozbratu między emigracją i krajem. [...] Ja myślę, że to właśnie ten ostracyzm, z jakim Miłosz się spotkał, to pewne odosobnienie ukształtowało jego niezwykle niechętny stosunek do polskiej diaspory ${ }^{43}$.

Ostatni akord burzliwych relacji Czesława Miłosza i Jana Nowaka-Jeziorańskiego wybrzmiał już w wolnej Polsce $\mathrm{i}$ wiązał się $\mathrm{z}$ pełnym insynuacji atakiem na Kuriera z Warszawy, jaki w 2001 roku przeprowadził Edward Moskal — przewodniczący Kongresu Polonii Amerykańskiej ${ }^{44}$. W przesiąkniętym antysemityzmem oświadczeniu zarzucił on Nowakowi m.in. współpracę z nazistami podczas wojny, co wywołało oburzenie w szerokich kręgach polskich elit — tym większe, że wkrótce miało dojść do wizyty Moskala w Polsce w związku ze zjazdem Polonii. Miłosz przyłączył się do głosów ostro potępiających to wystapienie i jego autora, biorących jednocześnie w obronę Nowaka. Razem ze Stanisławem Lemem, Krzysztofem Pendereckim, Jackiem Woźniakowskim, Krystyną Zachwatowicz i Andrzejem Wajdą podpisał list „Do władz samorządowych Krakowa" ${ }^{45}$. Biorąc pod uwagę sam ów list, można by się pokusić o próbę podsumowania relacji Miłosza i Nowaka w duchu ,szczęśliwego zakończenia”, jednak rzeczywistość okazała się ponownie znacznie bardziej skomplikowana. Oto jak przedstawiało się tło całej sprawy w zapiskach Agnieszki Kosińskiej, sekretarki poety:

24 kwietnia 2001, wtorek

Praca z CM: m.in. sprawa Międzynarodowego Festiwalu Literackiego w Berlinie. Afera z apelem „Do władz samorządowych Miasta Krakowa”, który przygotowała Krystyna Zachwatowicz, a Tomek Fiałkowski zredagował. Apel mieli złożyć honorowi obywatele Krakowa (CM, Lem, Woźniakowski) i odznaczeni medalem Cracoviae Merenti (Penderecki, Zachwatowicz i Wajda), przeciwko Edwardowi Moskalowi i jego oszczerstwom rzuconym na - jak się mówi w apelu — „człowieka nieskazitelnego" Jana Nowaka-Jeziorańskiego. Miłosz, jak to zobaczył, wściekł się: „To jest pułapka. Dlaczego ja mam podpisywać takie rzeczy!? Mogę podpisać apel przeciwko antysemickim wystąpieniom Moskala, ale tu oczywiście chodzi o Nowaka. Co do Nowaka, to on wyczyniał rzeczy straszne jako dyrektor Radia Wolna Europa. Montował akcję przeciwko Mackiewiczowi, bo między innymi podejrzewał go o projekt zabierania mienia żydowskiego, co było zresztą nieprawdą. W każdym razie jestem w posiadaniu tych dokumentów ${ }^{46}$. Ja do Wolnej Europy nie należałem, bo tam co drugie słowo kropili: radio z kropidłem w tle. Ani do Kongresu Polonii, gdzie należał Moskal i Jeziorański. To w ogóle nie moje tereny. Owszem, śledziłem zachowania Moskala w Ameryce, oburzałem się, ale nie oficjalnie. I teraz taka sprawa. Nie, ja tego apelu nie podpiszę. Zadzwońmy do Lema. Spróbuję go przekonać”.

Dzwonimy do Lema. Jest około piątej po południu. Lemowa mówi: „Zaraz poszukam go. Niestety nie ma. Wyszedł. Proszę dzwonić później, a najlepiej jutro przed południem".

A.K.: To może Woźniakowski.

CM: No, Woźniakowski jest bliżej Nowaka.

Jacka Woźniakowskiego nie było, ale była żona, zdecydowanie bliżej Nowaka.

${ }^{43}$ Otwierać okna i drzwi do Polski. Z Janem Nowakiem-Jeziorańskim rozmawia Aleksandra Ziótkowska, [w:] J. Nowak-Jeziorański, W poszukiwaniu nadziei, s. 287-288.

${ }^{44}$ E. Moskal, Faryzejskie wzywanie innych do przeprosin, Dziennik Związkowy (Chicago), 12.04.2001.

${ }^{45}$ Gazeta Wyborcza (Kraków) 2001 nr 98, s. 2.

${ }^{46}$ Dokumentów dotyczących akcji przeciwko Józefowi Mackiewiczowi [przyp. A.K.]. 
W końcu, w następnym dniu, CM wypertraktował, że układ nazwisk pod apelem będzie alfabetyczny, a więc CM nie będzie pierwszy (ale drugi), oraz wykreśli się sformułowanie: „szkalujących dobre imię Jana Nowaka-Jeziorańskiego” i „nieskazitelność”, a zamiast tego: „obrażających Jana Nowaka-Jeziorańskiego - laureata Srebrnego Medalu Cracoviae Merenti" $[\ldots]^{47}$.

Nie ma zatem mowy o „happy endzie” ani o swojskim zbrataniu się ponad podziałami w późnych latach. Jedyne, co było w stanie zbliżyć nieco stanowiska Miłosza i Nowaka do siebie w tym czasie, to kwestie absolutnie fundamentalnego militarnego bezpieczeństwa Polski w obliczu kryzysu i krytyki ze strony krajów Europy Zachodniej, jakie spotkały NATO po rozpoczęciu interwencji w Iraku w 2003 roku. Swoista nagonka na Stany Zjednoczone, która rozpętała się m.in. we Francji i w Niemczech, skłoniła poetę do przyznania racji legendarnemu kurierowi i stanięcia $\mathrm{z}$ nim $\mathrm{w}$ tej sprawie $\mathrm{w}$ jednym rzędzie:

[...] nie można bezkarnie rugować USA z Europy. Cokolwiek mam do Nowaka-Jeziorańskiego, to jednak jest inteligentny człowiek. Powiedział to samo co ja w wypowiedzi o obecnym stanie NATO, Iraku. Że dla Polski to śmierć, jeśli Niemcy się z Francją porozumieją i wykurzą Amerykę z Europy ${ }^{48}$.

Z dzisiejszej perspektywy wiele pozwala sądzić, że to przede wszystkim ogromne ambicje i Miłosza, i Nowaka w głównej mierze nie pozwalały im przyznać wzajemnie przed sobą, że cel ich podróży, cel, który w znacznej mierze został osiągnięty przez Polskę i Polaków w 1989 roku, był wspólny. Pytaniem bez odpowiedzi pozostanie już, czy obecna coraz trudniejsza sytuacja w Europie i relacjach transatlantyckich paradoksalnie nie skłoniłyby ich do przesunięcia obustronnych urazów i ambicji na dalszy plan i do energiczniejszych poszukiwań skutecznego porozumienia, wykorzystującego pełnię pokaźnego w tej mierze potencjału.

\section{LITERATURA}

Archiwum Jana Nowaka-Jeziorańskiego, Zakład Narodowy im. Ossolińskich we Wrocławiu (Korespondencja 1944-1975, sygn. 82-100/99, t. 32);

Archiwum Miłosza w Beinecke Rare Book and Manuscript Library: materiały dot. RWE (Czeslaw Milosz Papers: series V: Professional Papers, box 178, folder 2772) oraz korespondencja (series I: Correspondence, box 52, folder 741).

J. Giedroyc, Autobiografia na cztery ręce, oprac. K. Pomian, Warszawa 1994;

—, Cz. Miłosz, Listy 1952-1963, oprac. i wstęp M. Kornat, Warszawa 2008;

—, - Listy 1964-1972, oprac. M. Kornat, Warszawa 2011;

—, - Listy 1973-2000, oprac. M. Kornat, Warszawa 2012;

A. Kosińska, Mitosz w Krakowie, Kraków 2015;

J. Kurski, Jan Nowak-Jeziorański. Emisariusz wolności, wstęp W. Bartoszewski, Warszawa 2005;

Cz. Miłosz, Ankieta w sprawie akcji 34-ch, Kontynenty $1964 \mathrm{nr} 67-68$;

—, Przyczynek do dziejów literatury na emigracji, Zeszyty Historyczne 2005 z. 152;

—, K.A. Jeleński, Korespondencja, red. B. Toruńczyk, oprac. R. Romaniuk, Warszawa 2011;

Nieukochani kmiotkowie, Na Antenie 1964 nr 10;

J. Nowak-Jeziorański, W poszukiwaniu nadziei, Warszawa 1993;

—, Fakty, wydarzenia, opinie, Warszawa 2001;

\footnotetext{
${ }^{47}$ A. Kosińska, Miłosz w Krakowie, Kraków 2015, s. 202-203.

48 Tamże, s. 394.
} 
-, Wojna w eterze, Kraków 2005;

—, J. Giedroyc, Listy 1952-1998, wyb., oprac. i wstęp D. Platt, Wrocław 2002;

K.W. Tatarowski, Literatura i pisarze w programie Rozglośni Polskiej Radia Wolna Europa, Kraków 2005;

V. Wejs-Milewska, Radio Wolna Europa na emigracyjnych szlakach pisarzy: Gustaw Herling-Grudziński, Tadeusz Nowakowski, Roman Palester, Czesław Straszewicz, Tymon Terlecki, Kraków 2008.

\section{CZESLAW MILOSZ AND JAN NOWAK-JEZIORANSKI—RECORDS OF DIVIERGENCES}

The article aims to discuss the context and reasons for the difficult relationship between Czesław Miłosz and Jan Nowak-Jeziorański, two prominent figures in Polish twentieth century history. The analysis of available material helps the reader understand that it was not just a personal conflict, but a clash of disparate visions of Polishness, divergent ideologies, as well as incompatible visions of patriotism, a particularly thorny issue in the Polish context. The factors discussed in the essay might explain why Czesław Miłosz was one of the few great Poles absent from Radio Free Europe.

KEY WORDS: Miłosz; Nowak-Jeziorański; Radio Free Europe; conflict; emigration; Miłosz and Radio Free Europe; Miłosz Radio Free Europe conflict; Miłosz Nowak-Jeziorański conflict. 